Discussion Paper No. 680

\title{
CREDIT ALLOCATION OF \\ JAPANESE BANKS IN THE 1990s: \\ EVIDENCE FROM \\ THE SHORT-TERM ECONOMIC SURVEY \\ OF ENTERPRISES
}

\author{
Kazuo Ogawa
}

January 2007

The Institute of Social and Economic Research

Osaka University

6-1 Mihogaoka, Ibaraki, Osaka 567-0047, Japan 
Discussion Paper No. 680

\title{
CREDIT ALLOCATION OF \\ JAPANESE BANKS IN THE 1990s: \\ EVIDENCE FROM \\ THE SHORT-TERM ECONOMIC SURVEY \\ OF ENTERPRISES
}

\author{
Kazuo Ogawa
}

January 2007

The Institute of Social and Economic Research

Osaka University

6-1 Mihogaoka, Ibaraki, Osaka 567-0047, Japan 
May 2005

Revised December 2006

Credit Allocation of Japanese Banks in the 1990s:

Evidence from the Short-term Economic Survey of Enterprises*

Kazuo Ogawa

Institute of Social and Economic Research,

Osaka University

* Earlier version of this paper was presented as an invited lecture at 2005 Spring Meeting of the Japan Economic Association held at Kyoto Sangyo University in June 4 and 5, 2005. This research was partially supported by Grants-in-Aid for Scientific Research 12124207 and 16330038 of the Ministry of Education. Any remaining errors are the sole responsibility of the author. 


\begin{abstract}
This study is an empirical attempt to investigate the effects of balance sheet deterioration of Japanese firms and banks during the 1990s on credit allocation using the Short-term Economic Survey of Enterprises. This survey includes a unique item: the proportion of firms perceiving the lending attitude to be severe. After developing a theoretical model to link this item with the balance sheet conditions of borrowers and lenders, we estimated the relationships that we derived from our model. We found that credit was reduced when the balance sheet of firms and banks deteriorated. The effects are particularly significant for non-manufacturing industries.
\end{abstract}

JEL Classification Number: E44, E51 and G21

Keywords: Tankan Survey, Credit crunch, Ever-greening, Non-performing loans, Corporate Debt

Correspondence to:

Institute of Social and Economic Research, Osaka University, 6-1 Mihogaoka, Ibaraki, Osaka, 567-0047 JAPAN

Tel: +81- 6- 6879-8570 Fax: +81- 6-6878-2766

E-mail: ogawa@iser.osaka-u.ac.jp 


\section{Introduction}

It is often argued that credit misallocation was responsible for the long stagnation of the Japanese economy during the 1990s. The case is set out as follows. Banks had concentrated their managerial resources around the disposal of massive, non-performing loans, which had prevented banks from playing the intermediary role of allocating funds more efficiently. Thus, the malfunction of the credit allocation system plunged the Japanese economy into a severe, decade-long stagnation. While few would refute this interpretation, a wide spectrum of opinion remains about the manner in which credit was misallocated in the economy.

One view is focused on what has been termed a "credit crunch" in the 1990s. The banks, burdened with bad loans, reduced the amount of bank loans granted to firms. Bank-dependent firms were forced to cut spending on fixed investments, which lowered aggregated production.

Another view is that associated with the "evergreening" of loans. It is profitable for a bank to continue, or even to increase, lending to insolvent firms if the bank has already spent a large sum of money on screening and monitoring loans to these firms, given that past expenses have already been sunk into this firm. Furthermore, additional loans to insolvent firms can delay the realization of loan losses. In other words, it is perfectly rational for a bank to continue to grant loans to inefficient firms in order to prevent the realization of loan losses. This is a well-known soft budget problem. ${ }^{1}$ From a theoretical perspective, it is difficult to settle the dispute over which interpretation of events is more plausible. Therefore, it is an issue that must be settled empirically.

This paper is an empirical attempt to shed light on this issue based on survey data from the Short-term Economic Survey of Enterprises (or the Tankan survey), reported by the Bank of Japan. The Tankan survey is unique in the sense that it contains data concerning firms' judgments on the credit conditions currently faced. The firms were asked to answer the following question: How do you perceive the current lending attitude of financial institutions? Firms were asked to choose one of the following three items: severe, not so severe, and accommodative. Each item reflects the credit condition the firm perceived itself to face. The Tankan survey reports the proportion of firms responding to each 
choice by aggregating the responses of individual firms.

Two benefits of the Tankan survey deserve special mention. First, it provides us with information on credit allocation viewed from the firms' perspective. It enables us to incorporate demand as well as supply factors associated with loans in analyzing credit allocations. Secondly, survey results are available by industry and firm size, so that we can examine differences in credit allocations across industries and firm size. The main contribution of this study is that it relates information on credit allocations in the Tankan survey to factors underlying loan demand and supply. In particular, we are interested in the ways in which deterioration of the balance sheets of firms and banks in the 1990s affected the allocation of credit.

To preview our main findings, the deterioration of firms' balance sheets in the 1990s raised the proportion of firms perceiving the lending attitude of financial institutions to be severe. This is most notable for non-manufacturing industries. Massive non-performing loans in the banking sector significantly raised the proportion of firms perceiving the lending attitude of financial institutions to be severe. This tendency is also notable for non-manufacturing industries, especially the real estate industry. Our results are irrespective of the choice of balance sheet variable with respect to the banks. Our evidence indicates that the credit crunch interpretation is more relevant than the evergreening interpretation in describing credit allocations at the industry level in the Japanese economy of the 1990s.

The paper is organized as follows. Section 2 reviews studies dealing with credit allocation and its association with the balance sheet conditions of Japanese firms and banks after the 1990s. We summarize previous findings on this issue. Section 3 sets up a simple theoretical model to analyze the relationship of credit allocations deduced from the Tankan survey with the factors underlying loan demand and supply. Section 4 derives equations that link the extent to which firms perceive the lending attitude of financial institutions to be severe with some underlying factors, including balance sheet variables of firms and banks. The data set we use is also explained in this section. Section 5 shows the results of our estimations and explains the implications of the manner in which credit was allocated in the 1990s at the industry level. Section 6 presents our conclusions. 
2. Credit Allocation and Balance Sheet Conditions of Firms and Banks: Literature Survey Here, we review empirical studies dealing with the effects of balance sheet conditions in Japanese firms and banks with respect to credit allocations after the 1990s. The empirical studies are divided into two positions. One position supports the idea that the deterioration of balance sheets in firms and banks had negative effects on credit allocation. These studies are numerous, including Yoshikawa et al. (1994), Miyagawa et al. (1995), Economic and Social Research Institute (1995), Maeda (1996), Peek and Rosengren (1997, 2000), Woo (1998), Ito and Sasaki (2002), Horie (2001), Honda (2002), Hosono (2006), Ohkusa (2002), and Ogawa (2003).

There are several characteristics common to these studies. First, almost all of the studies investigated the effects of banks' capital adequacy ratio and ratio of non-performing loans to total loans on credit allocation. Many of the studies obtained significantly positive effects with respect to the capital adequacy ratio and significantly negative effects with the non-performing loans ratio in relation to bank loans. In other words, the credit crunch hypothesis is supported by these studies. It is true that, in these studies, the factors affecting demand for bank loans were partially controlled for; however, they only estimate the supply schedule of bank loans. One exception is Ohkusa's study (2002), in which the level and growth rate of firms' profits are shown to be important factors that influence the lending attitude of financial institutions. Given that it is not an easy task to thoroughly identify demand and supply with respect to bank loans, it would be preferable to include not only factors affecting bank loan supply but also those affecting demand for bank loans.

Second, most of these studies examine total bank loans, with the exception of Miyagawa et al. (1995), Maeda (1996) and Ogawa (2003). They divide loans into several components and pay special attention to the relationships between banks' balance sheet conditions and bank loans to small firms. Ogawa's study (2003) revealed evidence suggesting that the effect of the non-performing loans ratio is particularly strong for loans to small firms. Moreover, Ogawa also examined the effect of the non-performing loans ratio on bank loans by industry and reported that the effect of the non-performing loans 
ratio on bank loans is larger for non-manufacturing industries.

The other position supports the explanation of the evergreening of loans. The studies providing evidence for this condition are relatively new. For example, Hoshi's study (2000) offers the seminal argument that evergreening of loans is apparent in the real estate industry. Studies by Fukao (2000) and Sakuragawa (2002) are in the same vein. The former shows that the average borrowings per firm increased for the real estate industry in the late 1990s, and the latter reports that the correlation between the rate of change in land price and lending to the real estate industry vanished in the late 1990s. More formal empirical works estimate the supply equation of bank loans. The balance sheet variables commonly used in these studies are the ratio of non-performing loans to total loans, banks’ capital adequacy ratio, and firms’ debt-asset ratio. Sasaki (2000) found that banks with a higher non-performing loans ratio tend to increase loans to the construction industry while Sugihara and Fueta (2002) also found that non-performing loans to the real estate industry exert a significantly positive effect on loans granted to this industry. Tsuru (2001) found that the capital adequacy ratio had significantly negative effects on loans made to the real estate industry. Hosono and Sakuragawa (2003) argued that banks with a lower capital adequacy ratio tend to increase real estate loans. The studies of Hibara (2001), Koyabashi et al. (2002), and Peek and Rosengren (2005) are unique in that they used matched samples of individual firms and bank lenders' transactions. By examining the relationship between the non-performing loans ratio and the debt-asset ratio, Hibara (2001) found that banks with higher non-performing loans ratios tended to use less restraint in making loans to firms with high debt-asset ratios. Koyabashi et al. (2002) showed that beyond a certain point of debt-asset ratio, a rise in the debt-asset ratio corresponded with an increase in lending to firms in the construction and real estate industries. Peek and Rosengren (2005) offer the most comprehensive micro study. They demonstrated that Japanese banks increased loans to less profitable firms in the 1990s. Moreover, they found that this was especially so for banks with balance sheet deterioration and loans to affiliated firms.

To summarize, first, the evergreening phenomena is not prevalent across industries but can be observed in certain, non-manufacturing industries (construction and real estate) 
that are burdened with excessive debt. Second, all of the studies that incorporate firms' balance sheet variables rely on micro data from banks and firms. Since listed firms' information constitutes the micro data, the evidence supporting the evergreening argument is confined to large firms, with no information concerning small or medium-sized firms included. ${ }^{2}$ It is worth noting that small or medium-sized firms are more dependent on bank loans, so investigation into how credit allocation is influenced by the balance sheet conditions of firms, as well as that of banks, is important. The benefit of examining micro data from firms and banks in the context of this study is that it enables us to make clear estimates of the effects of balance sheet conditions of firms and banks on credit allocation. However, we fail to obtain macro or industry level implications for credit allocations from micro level evidence. It is true that credit is constrained for some firms with heavy debts and is expanded for some firms with excessive debts, but micro level evidence is silent as to the aggregated consequences of credit allocations on the industry level. In the subsequent sections, we investigate how credit is allocated for small and medium-sized firms as well as large firms. The Tankan survey is an ideal data source that provides us with the information necessary for conducting empirical analysis along these lines.

3. Credit Allocation and Balance Sheet Conditions of Firms and Banks: Theoretical Framework

We set up a simple theoretical model to analyze how credit allocation across firms within an industry is associated with the balance sheet conditions of firms constituting an industry and banks. We assume that the i-th firm in a certain industry has the following demand schedule for bank loans:

$$
L_{i t}^{d}=f\left(y_{i, 1 t}, y_{i, 2 t}, \cdots, y_{i, n t}\right)
$$

where $L_{i t}^{d}$ : demand for bank loans of the $\mathrm{i}$-th firm in time $\mathrm{t}$

$$
y_{i, k t} \text { : determinants of loan demand of the i-th firm in time } \mathrm{t}(k=1,2, \cdots, n)
$$

Denote the supply schedule of loans to the i-th firm by $L_{i t}^{s} \cdot{ }^{3}$ The supply schedule of loans 
is given by:

$$
L_{i t}^{s}=g\left(y_{i, 1 t}, y_{i, 2 t}, \cdots y_{i, n t}, z_{1 t}, z_{2 t}, \cdots, z_{p t}\right)
$$

where $z_{k t}$ :determinants of loan supply in time $t(k=1,2, \cdots, p)$

It should be noted that the loan schedule is influenced not only by the factors associated with banks, such as the banks' balance sheet, but also by the factors that affect loan demand. This is because a loan contract is intrinsically determined by negotiation between creditors and debtors, and information concerning debtors is processed by banks in determining the supply of loans to the firm. ${ }^{4}$

When the demand schedule for loans exceeds the supply schedule, the firm may perceive the current lending attitude of financial institution to be severe. Let $\theta_{i t}$ be the extent to which the supply schedule exceeds demand schedule, or:

$$
\theta_{i t}=\frac{L_{i t}^{s}}{L_{i t}^{d}}-1
$$

Then, $\theta_{i t}$ can capture the extent to which the firm perceives the present lending attitude to be severe. The Tankan survey we used for data in our empirical analysis reports the percentage share of firms regarding the current lending attitude as severe, not so severe and accommodative, respectively. These ratios were easily translated into our framework. Figure 1 shows the distribution of $\theta_{i t}$ across firms within a certain industry. We denote the percentage share of firms feeling the present lending attitude to be severe, not so severe, and accommodative as $S_{t} N S_{t}$, $A_{t}$, respectively. Then, we have:

$$
\begin{aligned}
& S_{t}=\int_{-\infty}^{-\delta_{1}} f\left(\theta_{i t}\right) d \theta_{i t} \\
& N S_{t}=\int_{-\delta_{1}}^{+\delta_{2}} f\left(\theta_{i t}\right) d \theta_{i t}
\end{aligned}
$$




$$
A_{t}=\int_{+\delta_{2}}^{+\infty} f\left(\theta_{i t}\right) d \theta_{i t}
$$

where $\delta_{1}$ : threshold to recognize the lending attitude as severe

$$
\delta_{2} \text { : threshold to recognize the lending attitude as accommodative }
$$

By specifying the density function, we can obtain more tractable expressions for eq.(4). We assume that the distribution function of $\theta_{i t}$ is given by the following logistic function:

$$
F\left(\theta_{i t}\right)=\frac{1}{1+e^{-\left(\theta_{i t}-\alpha\right) / \beta}}
$$

where $\alpha, \beta$ :shift parameters $\beta>0$

Since $\theta_{i t}$ is defined as the ratio of supply to demand for loans, it is a function of the factors affecting both supply and demand for loans. In other words, the shape of the distribution hinges upon $y_{i, 1 t}, y_{i, 2 t}, y_{i, 3 t}, \cdots, y_{i, n t}, z_{1 t}, z_{2 t}, z_{3 t}, \cdots, z_{p t}(i=1,2, \cdots, I)$, where I is the number of firms. These variables are the driving force of the shift parameters. Since it is impossible to incorporate the information of individual firms into our analysis, we assume that the shift parameter $\alpha$ is a function of the mean of firm attributes. We denote the mean of $y_{i, 1 t}, y_{i, 2 t}, y_{i, 3 t}, \cdots, y_{i, n t}$ across firms by $\bar{y}_{1 t}, \bar{y}_{2 t}, \cdots, \bar{y}_{n t} \cdot{ }^{5}$ Then, $\alpha$ is expressed as follows:

$$
\alpha=h\left(\bar{y}_{1 t}, \cdots, \bar{y}_{n t}, z_{1 t}, \cdots, z_{p t}\right)
$$

From this, we can link the proportion of firms perceiving the present lending attitude to be severe $\left(S_{t}\right)$ with the factors underlying supply and demand for loans.

$$
S_{t}=\frac{1}{1+e^{-\left(-\delta_{1}-h\left(\bar{y}_{1 t}, \cdots, \bar{y}_{t}, z_{1 t}, \cdots, z_{p t}\right)\right) / \beta}}
$$


In our framework, the effects of factors affecting loan demand and supply on $S_{t}$ may be easily analyzed. For example, the effect of deterioration of a bank's balance sheet on $S_{t}$ can be examined in the following manner. Suppose that deterioration of the bank's balance sheet makes the bank more reluctant to supply loans to firms. It will lower $\theta_{i t}$ for some firms, and the distribution function of $\theta_{i t}$ will shift to the left, as shown in Figure 2. Thus, the proportion of firms perceiving the lending attitude to be severe rises.

However, the bank might increase loans as a result of soft budget problems when the bank's balance sheet deteriorates. Then, it will raise $\theta_{i t}$ for some firms, and the distribution function of $\theta_{i t}$ will correspondingly shift to the right. This implies that the proportion of firms perceiving the lending attitude to be severe falls. This case is that of the evergreening of loans. In actuality, some firms might observe a rise of $\theta_{i t}$ while others might observe a fall of $\theta_{i t}$. Therefore, the question of whether the proportion of firms perceiving the lending attitude to be severe increases or not is purely an empirical issue.

In a similar fashion, we can analyze the effects of factors affecting loan demand on $S_{t}$. Suppose that the outlook for the firm's profitability becomes gloomy. Then, the firm will decrease demand for loans. This will raise $\theta_{i t}$ and the percentage share of firms perceiving the lending attitude to be severe will fall. However, when the bank finds out the firm's gloomy profit expectations, a decrease of loan demand might be accommodated. This might lead to a fall of $\theta_{i t}$ and the proportion of firms feeling the lending attitude to be severe might rise. This illustrates the importance of firms' information to the banks' loan supply decisions; it also shows that the question of whether banks accommodate a change in loan demand hinges upon firms' information as well as on the ways in which banks process such information. This is an empirical issue to be investigated in subsequent sections.

It should be noted that we can also link the proportion of firms perceiving the present lending attitude to be accommodative $\left(A_{t}\right)$ to the factors underlying the demand and supply schedule of loans. It is written as: 


$$
A_{t}=1-\frac{1}{1+e^{-\left(\delta_{2}-h\left(\bar{y}_{1 t}, \cdots, \bar{y}_{n t}, z_{1 t}, \cdots, z_{p t}\right)\right) / \beta}}=\frac{1}{1+e^{\left(\delta_{2}-h\left(\bar{y}_{t t}, \cdots, \bar{y}_{n t}, z_{1 t}, \cdots, z_{p t}\right)\right) / \beta}}
$$

This equation is estimated jointly with eq.(7).

\section{Framework of Empirical Investigation and Data Set}

In the previous section, we derived the basic equation to link the proportion of firms perceiving the lending attitude to be severe or accommodative with the factors underlying loan demand and supply. The purpose of this section is twofold. One is to modify the basic equations and derive the equation to estimate the effects of the factors underlying supply and demand for loans on credit allocation. The other is to explain the data set we used in the estimation as well as the procedures for constructing the variables.

\section{A. Specification of Lending Attitude Equation}

In estimating eqs.(7) and (8), the shift parameter of $\alpha$ is specified as a linear function of the factors underlying loan demand and supply. We selected the following variables that affect loan demand. They are liquidity measure (LIQ), growth potential (GROWTH), and balance sheet condition of firms (FBALANCE). As for the variables that affect loan supply, we chose the balance sheet variable of banks (BBALANCE).

Specifically, the equation linking the proportion of firms perceiving the lending attitude of financial institutions to be severe $\left(S_{t}\right)$ with the factors underlying loan demand and supply is written as:

$$
S_{t}=\frac{1}{1+e^{\Phi_{t}}}
$$

where

$$
\begin{aligned}
\Phi_{t} & =\gamma_{1}+\gamma_{2} \text { GROWTH }_{t}+\gamma_{3} L_{I} Q_{t}+\gamma_{4} \text { FBALANCE }_{t}+ \\
& +\gamma_{5} B B A L A N C E_{t}+\gamma_{6} \text { FBALANCE }_{t} \times B B A L A N C E_{t} \\
\gamma_{1} & =\frac{\delta_{1}}{\beta}
\end{aligned}
$$


An increase of firms' liquidity may decrease the demand for loans and lead to a fall in $S_{t}$ by way of a rise in $\theta_{i t}$. Thus, the coefficient $\gamma_{3}$ is positive. Higher growth potential will increase the demand for loans. It will lower $\theta_{i t}$ and $S_{t}$ will rise as long as banks do not accommodate the increase of loan demand. On the other hand, when banks accommodate an increase in loan demand, it might be the case that $\theta_{i t}$ rises and $S_{t}$ falls. Therefore the sign of $\gamma_{2}$ is indeterminate a priori.

Deterioration of firms' balance sheets, leading to the reduction of demand for loans, may also reduce loan supply if banks are aware of firms' balance sheet deteriorations. When the reduction of loan supply by banks is larger than that of loan demand, $\theta_{i t}$ will fall and $S_{t}$ will rise. In this case, the coefficient $\gamma_{4}$ is negative. However, if the firms increase their demands for loans in spite of the deterioration of their balance sheets, to repay debt, for example, and banks support this decision by increasing loan supply, it may raise $\theta_{i t}$ and $S_{t}$ will fall $\left(\gamma_{4}>0\right)$. This case can be interpreted as an example of the evergreening of loans.

Deterioration of banks' balance sheets generally reduces loan supply, which lowers $\theta_{i t}$ and raises $S_{t}$. In other words, the coefficient $\gamma_{5}$ is negative. However, when the banks boost loan supply, in spite of the deterioration of their balance sheets, it lowers $S_{t}$ $\left(\gamma_{5}>0\right)$. This also corresponds to the case of evergreening of loans. To sum up, we can determine whether evergreening of loans is prevalent by examining the sign of the coefficients of FBALANCE and/or BBALANCE.

We added the cross term of the firms' balance sheet conditions with that of the banks' to measure the interaction between the balance sheets of the two sectors. The cross term plays an important role in strengthening or weakening the individual balance sheet effects. When $\gamma_{6}$ is negative, it will enhance the effects of credit crunch, whereas when $\gamma_{6}$ is positive it will enhance the effects of evergreening.

Lastly, we take account of the differential effects of balance sheet conditions of firms and banks on credit allocation by industry and firm size. As we pointed out in Section 2, the evergreening phenomenon has been found mainly in non-manufacturing industries burdened with excessive and outstanding debt. Moreover, small firms are more bank-dependent, so the bank relationship might be special to small firm clients. This 
suggests that evaluation of firms' balance sheet conditions by banks might have a differential impact on banks' lending attitudes toward small firms. To take these possibilities into consideration, we add the cross term of balance sheet variables of firms and banks, with dummy variables for industry and firm size, to eq.(9). ${ }^{6}$ That is, we have:

$$
S_{t}=\frac{1}{1+e^{\Phi_{t}}}
$$

where

$$
\begin{aligned}
& \Phi_{t}=\gamma_{1}+\gamma_{1, S} D_{U M} S_{t}+\gamma_{1, M} D_{U M}+\sum_{k=1}^{q} \gamma_{1, I k} D_{U M I N D} \\
& +\gamma_{2} \text { GROWTH }_{t}+\left(\gamma_{3}+\gamma_{3, S} D_{U M} S_{t}+\gamma_{3, M} D U M M_{t}\right) \times \Delta L I Q_{t} \\
& +\left(\gamma_{4}+\gamma_{4, S} D_{U M S_{t}}+\gamma_{4, M} D U M M_{t}+\sum_{k=1}^{q} \gamma_{4, l k} D U M I N D_{k t}\right) \times \Delta F B A L A N C E_{t} \\
& +\left(\gamma_{5}+\gamma_{5, S} D_{U M S_{t}}+\gamma_{5, M} D_{U M M_{t}}+\sum_{k=1}^{q} \gamma_{5, l k} D U M I N D_{k t}\right) \times \Delta B B A L A N C E_{t}
\end{aligned}
$$

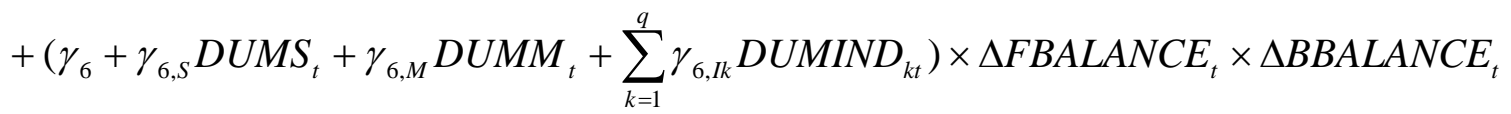

where $D U M S_{t}$ : dummy variable for small firms

$D U M M_{t}$ : dummy variable for medium-sized firms

$D U M I N D_{k t}$ :dummy variable for the k-th industry $(k=1,2, \cdots, q)$

It should also be noted that all the explanatory variables except growth potential are in first difference form. ${ }^{7,8}$

In a similar fashion, we can write the proportion of firms perceiving the present lending attitude to be accommodative $\left(A_{t}\right)$ as a function of factors underlying supply and demand for bank loans as follows:

$$
S_{t}=\frac{1}{1+e^{\Psi_{t}}}
$$

where 


$$
\begin{aligned}
& \psi_{t}=\varepsilon_{1}+\varepsilon_{1, S} D_{U M}+\varepsilon_{1, M} D U M M_{t}+\sum_{k=1}^{q} \varepsilon_{1, I k} D U M I N D_{k t} \\
& -\gamma_{2} \text { GROWTH }_{t}-\left(\gamma_{3}+\gamma_{3, S} D_{U} \mathrm{DS}_{t}+\gamma_{3, M} \mathrm{DUMM}_{t}\right) \times \Delta L I Q_{t} \\
& -\left(\gamma_{4}+\gamma_{4, S} D U M S_{t}+\gamma_{4, M} D U M M_{t}+\sum_{k=1}^{q} \gamma_{4, l k} D U M I N D_{k t}\right) \times \Delta F B A L A N C E_{t} \\
& -\left(\gamma_{5}+\gamma_{5, S} D U M S_{t}+\gamma_{5, M} D_{U M M_{t}}+\sum_{k=1}^{q} \gamma_{5, l k} D_{U M I N D_{k t}}\right) \times \Delta B B A L A N C E_{t} \\
& -\left(\gamma_{6}+\gamma_{6, S} D U M S_{t}+\gamma_{6, M} D U M M_{t}+\sum_{k=1}^{q} \gamma_{6, l k} D U M I N D_{k t}\right) \times \Delta F B A L A N C E_{t} \times \Delta B B A L A N C E_{t}
\end{aligned}
$$

Note that the coefficient of each explanatory variable in eq.(11) has the reverse sign of eq.(10).

\section{B. Data Set Description and Construction of Variables}

The Tankan survey reports, on a quarterly basis, the proportion of firms perceiving the lending attitude of financial institutions to be severe by industry and firm size. Sample firms are private firms selected from the population of all firms in Japan employing 50 or more persons (or 20 or more persons for wholesale, retail, and leasing industries). The Tankan survey classifies industries into 17 manufacturing and 10 non-manufacturing industries. We chose 14 manufacturing and six non-manufacturing industries with available balance sheet information. ${ }^{9}$ Sample firms are classified by size into large, medium, and small firm groups based on the number of employees. Large firms are defined as those with a number of employees over 1,000. Medium-sized firms are defined as those with a number of employees between 300 and 1,000. Small firms are defined as those with a number of employees below $300 .{ }^{10}$ Our sample period covers the second quarter of 1983 to the first quarter of 2003. In our data, we pooled all of our observations across industry and firm size, so that observations total 4,800 $(=80 \times 20 \times 3)$.

The explanatory variables of loan demand are taken from the Financial Statements Statistics of Corporations by Industry (abbreviated as FSSC), issued by the Ministry of Finance. A variety of items on firms' balance sheets as well as profit and loss accounts are reported on a quarterly basis by industry and firm size. One difficulty of matching the Tankan survey with the FSSC lies in the difference of size classification. The former 
classifies by the number of employees, while the latter classifies by equity capital. We assume that the firms whose equity capital exceeds one billion yen correspond to large firms in the Tankan survey. Similarly, the firms whose equity capital is between 0.1 and 1 billion yen correspond to medium-sized firms in the Tankan survey, and the firms whose equity capital is below 0.1 billion yen correspond to small firms in the Tankan survey. Although the two definitions of firm size are different, it turns out that they are closely related. In the FSSC, the average number of employees in the fiscal year of 2003 is 16.3, 167.6, and 1192.1 for small, medium-sized, and large firm groups, respectively, across all industries.

Liquidity is measured by the ratio of cash, deposit, and securities balance plus ordinary income and depreciation allowance, to sales. Growth potential (GROWTH) is measured by the growth rate of real sales. The balance sheet variable of the firm (FBALANCE) is measured by the ratio of short-term and long-term borrowings to market-valued land stock. Land stock is constructed by the perpetual inventory method. ${ }^{11}$ Since land is the most popular form of collateral in Japan, this ratio reflects the extent to which actual borrowings exceed firms' borrowing capacities or the degree of excess borrowings. The balance sheet variable of the bank (BBALANCE) is the ratio of allowance for doubtful loans to total loans. This variable is a proxy for the ratio of non-performing loans to total loans and is the only one available on a quarterly basis. The balance sheet variables we use are dated at the beginning of the period to avoid simultaneity bias. The variables of firm attributes are on a per firm basis and all of the variables are seasonally adjusted. ${ }^{12}$

Table 1 shows the sample mean of the ratio of borrowing outstanding to market-valued land stock. The ratio is higher for non-manufacturing industries. It hovers at around unity for small firms, except for the service industry. The ratio tends to be highest for large firms, except for those in retail and the real estate industries. For manufacturing industries, there is less regularity on the magnitude of the ratios across industry and firm size. Table 2 shows the average growth rate of real sales. Negative sales growth was dominant in most of the industries, reflecting severe stagnation in the 1990s. In particular, the growth rate of real sales was negative, irrespective of firm size, for food, steel, fabricated metals, construction, and retail industries. In contrast with stagnant industries, there were 
industries that exhibited positive growth rate, irrespective of firm size. These were chemicals, electrical machinery, transportation machinery, and transportation and information communication industries.

\section{Estimation Results and Their Implications for Credit Allocation}

\section{A. Estimation Results of Lending Attitude Equation}

Here, we turn to our estimation results that indicate some important implications for credit allocation. Eqs.(10) and (11) are jointly estimated by nonlinear least squares. Estimation results are shown in Table $3 .^{13}$ As we expected, the coefficient estimate of liquidity is positive and statistically significant at the $1 \%$ level. Increase of firms' liquidity reduces demand for loans and hence decreases the proportion of firms perceiving the lending attitude to be severe. There was no discernible difference in the effects of liquidity on the proportion of firms perceiving the lending attitude to be severe among small, medium-sized, and large firms. The coefficient estimate of sales growth rate is significantly positive. It implies that higher growth potentials decrease the proportion of firms perceiving the lending attitude to be severe by inducing banks to accommodate firms' increased loan demand.

\section{B. Implications for Credit Allocation: Credit Crunch or Evergreening?}

Based on the coefficient estimates of the balance sheet variables of firms and banks, we can infer how changes in the balance sheet conditions of firms and banks affect credit allocation. If deterioration of balance sheet conditions tightens credit allocations, then we observe a credit crunch. On the other hand, if a deterioration of balance sheet conditions loosens credit allocations, then we observe evergreening. Our estimation results have the advantage that we can examine the effects of balance sheet conditions on credit allocation by industry and firm size.

We conducted our investigation in three different ways. First, we examined the coefficient estimates of the cross term of firms' balance sheet conditions with those of banks. ${ }^{14}$ It is easily shown that the effects of change in the balance sheet conditions of firms and banks regarding credit allocation is calculated from eq.(10) as: 


$$
\begin{aligned}
& \frac{\partial S_{t}}{\partial\left(\Delta F B A L A N C E_{t}\right)}=-S_{t}\left(1-S_{t}\right)\left\{\gamma_{4}+\gamma_{4, S} D U M S_{t}+\gamma_{4, M} D U M M_{t}+\sum_{k=1}^{q} \gamma_{4, k} D U M I N D_{k t}\right. \\
& \left.\left.+\left(\gamma_{6}+\gamma_{6, S} D U M S_{t}+\gamma_{6, M} D U M M_{t}+\sum_{k=1}^{q} \gamma_{6, l k} D U M I N D_{k t}\right) \times \Delta B B A L A N C E_{t}\right)\right\} \\
& \frac{\partial S_{t}}{\partial\left(\triangle B B A L A N C E_{t}\right)}=-S_{t}\left(1-S_{t}\right)\left\{\gamma_{5}+\gamma_{5, S} D U M S_{t}+\gamma_{5, M} D U M M_{t}+\sum_{k=1}^{q} \gamma_{5, k} D U M I N D_{k t}\right. \\
& \left.\left.+\left(\gamma_{6}+\gamma_{6, S} D U M S_{t}+\gamma_{6, M} D U M M_{t}+\sum_{k=1}^{q} \gamma_{6, l k} D U M I N D_{k t}\right) \times \Delta F B A L A N C E_{t}\right)\right\}
\end{aligned}
$$

When the cross term coefficient, the last term of the R.H.S. of eq.(12), is positive, deterioration of the balance sheet of one sector will mitigate the tightening effect of the balance sheet deterioration of the other sector on credit allocation. Thus, it is interpreted as evergreening. Table 4 shows the coefficient estimates of the cross term by industry and firm size. The significant cross terms are all negative for large firms. There is only one significantly positive cross term (petroleum and coal products industry) for medium-sized firms. For small firms, there is also one industry (industrial machinery industry) that has a significantly positive cross term. Judging from the cross term coefficients of firms' balance sheets and banks' balance sheets, evergreening does not seem to be prevalent in the economy.

The second way to examine these effects of balance sheet conditions of firms and banks on credit allocation is to calculate directly the effects of changes in the balance sheet conditions of firms and banks on the proportion of the firms perceiving the lending attitude to be severe, as is shown in eq.(12). We evaluate eq.(12) by industry and firm size based on the sample mean of $S_{t}, \triangle F B A L A N C E_{t}$ and $\triangle B B A L A N C E_{t}$ over the fourth quarter of 1997 to the first quarter of 2002, a period of financial turmoil. Tables 5 and 6 show the estimates of $\frac{\partial S_{t}}{\partial\left(\triangle F B A L A N C E_{t}\right)}$ and $\frac{\partial S_{t}}{\partial\left(\triangle B B A L A N C E_{t}\right)}$ calculated in this 
manner.

Deterioration of firms' balance sheet conditions significantly increases the proportion of firms perceiving the lending attitude to be severe, across all industries, for large firms. This implies that credit allocation tightens as the balance sheets of large firms deteriorate. A similar tendency is observed, though less dramatically, for medium-sized and small firms. For medium-sized and small firms, we observed negative effects of firms' balance sheet deteriorations on the proportion of firms perceiving the lending attitude to be severe for petroleum and coal products, non-ferrous metals, and service industries. It is significant only for small firms in the petroleum and coal products industries. In 18 out of 20 industries, we observed significantly positive effects for medium-sized firms, while we observed significantly positive effects in 11 industries for small firms. It should be noted that the estimates are notably large for retail, construction, and fabricated metals industries, irrespective of firm size.

A rise of the non-performing loan ratio makes banks' lending attitudes more severe for large and medium-sized firms across all industries, apart from the lumber and wood products industry. The rise of the non-performing loan ratio makes banks' lending attitudes more accommodative for small firms in lumber and wood products, fabricated metals, industrial machinery, transportation machinery, and construction industries. However, the effect is significant only in the lumber and wood products industry. Credit contraction effects are significant in four, 11, and 10 industries out of 20 for small, medium-sized, and large firms, respectively. The effects are particularly significant in the real estate industry, in which a rise of the ratio of allowance for doubtful loans to total loans by a single percentage point increases the proportion of firms perceiving the lending attitude to be severe by 15.1, 20.4 and 19.9 percentage points for small, medium-sized, and large firms, respectively. In the late 1990s, evergreening was seldom observed on an industry level, irrespective of firm size. Rather, we observed a serious credit crunch situation, especially in non-manufacturing industries.

Lastly, we show inter-industry evidence on the effects of firms' balance sheet conditions on credit allocation. This can be accomplished by calculating the correlation 
coefficient of the $\frac{\partial S_{t}}{\partial\left(\triangle F B A L A N C E_{t}\right)}$ and $\frac{\partial S_{t}}{\partial\left(\triangle B B A L A N C E_{t}\right)}$ estimates obtained above with the firms' balance sheet conditions across industries. When credit crunch is prevalent, we will see that the effects of change in balance sheet conditions on lending attitude is particularly severe for industries with deteriorating balance sheets. That is, we will observe positive correlations between the estimates of $\frac{\partial S_{t}}{\partial\left(\triangle F B A L A N C E_{t}\right)}$ and $\frac{\partial S_{t}}{\partial\left(\triangle B B A L A N C E_{t}\right)}$ with the firms' borrowings-land ratio. On the other hand, when evergreening is prevalent, deterioration of balance sheets will mitigate the effects of change in balance sheet conditions on lending attitude. In this case we will observe negative correlations. The correlation coefficient between the $\frac{\partial S_{t}}{\partial\left(\triangle B B A L A N C E_{t}\right)}$ estimate and the firms' balance sheet conditions, calculated by combining all the observations across firm size, is 0.3314 , and is significant. ${ }^{15}$ It indicates that the credit-tightening effect is more severe for industries with firms showing more balance sheet deterioration. This is evidence for a credit crunch condition, not for an evergreening of loans situation.

\section{Is Our Evidence Robust?: Estimation under Alternative Specifications}

The estimation results obtained so far lend support for the prevalence of credit crunch rather than evergreening on an industry level. We examine the robustness of our evidence by estimating the lending attitude equation under alternative specifications. We replace the banks' balance sheet variable with the rate of change in share price of the banking sector. The previous measure, the ratio of allowance for doubtful loans to total loan, shows how bad the firms' balance sheet conditions are on the basis of accounting information. It is often argued that balance sheet information is not reliable because of “window dressing.” In this case, a market-based measure of balance sheet conditions is more relevant. It would be legitimate to assume that share prices in the banking sector reflect the evaluation of bank health by the market. It turns out that the coefficient 
estimates of liquidity and growth rate of sales under these new specifications are quite similar to those of the previous case. Thus, our focus here is on how the balance sheet conditions of firms and banks affect credit allocation. This is investigated in three different ways, as in the previous case. Table 7 shows the cross term of the firms' balance sheet with the rate of change in share price of the banking sector. Since a rise in the rate of change in banks' share prices reflects the improvement of banks' balance sheets, a negative cross term corresponds to the evergreening case. It is only in the real estate industry that we observe evergreening, irrespective of firm size. ${ }^{16}$ Our evidence for evergreening in the real estate industry lends empirical support to previous studies. However, it should be noted that the prevalence of evergreening, judging from the sign of the cross term, is weak, given that even if the cross term is negative, the total effects of balance sheet deterioration on credit allocation calculated by eq.(12) could also support the credit crunch hypothesis. In fact, the deterioration of balance sheet conditions on the part of banks and firms leads to a more severe lending attitude for the real estate industry, irrespective of firm size, as will be seen below.

Here, we examine the $\frac{\partial S_{t}}{\partial\left(\triangle F B A L A N C E_{t}\right)}$ and $\frac{\partial S_{t}}{\partial\left(\triangle B B A L A N C E_{t}\right)}$ estimates, shown in Tables 8 and 9. Deterioration of firms' balance sheets significantly increases the proportion of firms perceiving the lending attitude to be severe for large firms across all industries. For medium-sized and small firms, we obtained negative estimates of $\frac{\partial S_{t}}{\partial\left(\triangle F B A L A N C E_{t}\right)}$ in petroleum and coal products, precision machinery, and service industries. All of the significant estimates are positive except for the petroleum and coal products industry, indicating the prevalence of credit crunch. As for the effects of banks' share price change on the credit allocation, a drop in the rate of change in banks' share prices increases the proportion of firms perceiving the lending attitude to be severe across all industries, except for the lumber and wood products industry, irrespective of firm size. In particular, the estimates are significantly negative and large in absolute value for the real estate industry, irrespective of firm size. 
Lastly, we calculate the correlation coefficients of the $\frac{\partial S_{t}}{\partial\left(\triangle F B A L A N C E_{t}\right)}$ and $\frac{\partial S_{t}}{\partial\left(\triangle B B A L A N C E_{t}\right)}$ estimates with the firms' balance sheet conditions across industries. The correlation coefficient between the $\frac{\partial S_{t}}{\partial\left(\triangle B B A L A N C E_{t}\right)}$ estimates and the firms' borrowings-land ratio, calculated by combining all the observations across firm size, is -0.2938 , and is statistically significant at the $5 \%$ level. ${ }^{17}$ Once again, the credit crunch hypothesis is supported by inter-industry comparison.

To sum up our evidence, balance sheet deterioration of firms and banks in the late 1990s reduced credit ubiquitously across industries. It should be noted that our evidence is not inconsistent with past studies that have argued for the evergreening case. This is because most of the studies that have obtained evidence favorable to evergreening have been conducted using micro data from firms. Our study uses more aggregated industry level data. As we pointed out in Section 3, it is true that deterioration of balance sheets has adverse effects on credit allocation to some firms, while other firms will perceive that the lending attitude gets more severe. Our examination of the proportion of firms perceiving the lending attitude to be severe, using evidence at the industry level, simply demonstrates that the number of firms suffering from the credit crunch condition is greater than those benefiting from evergreening.

\section{Concluding Remarks}

Empirical data on how balance sheet deterioration of firms and banks affected credit allocation in the 1990s revealed that credit allocation was reduced as a whole. The extent to which each industry suffered from credit reduction depends on the attributes of individual industries as well as the banking sector. The effects were notably large for the non-manufacturing sector, although the effects are not uniform across industries in the manufacturing sector. There remains another, more important, task to be completed: an investigation into how credit allocation in the 1990s affected the resource allocation of the economy. This is a promising avenue for future work, one that could lead to a deeper 
understanding of the economic mechanisms of the last decade. 18 


\section{Footnotes}

${ }^{1}$ See Dewartripont and Maskin (1995) and Berglof and Röland $(1995,1997)$ for detailed discussions of the soft budget problem.

${ }^{2}$ An exception is the study by Fukuda et al. (2005) in which the reduced form of the loan equation is estimated using a matched sample of unlisted firms and banks. The results are mixed. Deterioration of firm health leads to reduction of bank loans, while deterioration of bank health increases bank loans.

${ }^{3}$ For simplicity, we assume that there is one representative bank that provides loans to all of the firms in the economy.

${ }^{4}$ Interest payment is also an endogenous variable determined as a part of loan contract, so that interest rate does not appear as an explanatory variable in the loan demand and supply schedule.

${ }^{5}$ The variables $z_{1 t}, \cdots, z_{p t}$ are associated with the representative bank, so that they can be interpreted as the mean of the attributes of total banks.

${ }^{6}$ The effect of liquidity on demand for bank loans might vary across firms of different sizes, so that we add the cross term of liquidity with dummy variables for firm size.

${ }^{7}$ We also add dummy variables of firm size and industry to the constant term of $\Phi_{t}$.

${ }^{8}$ As will be explained below, growth potential is measured by the growth rate of real sales. Therefore, we do not take first difference of it.

${ }^{9}$ These are textiles, lumber and wood products, paper and pulp, chemicals, petroleum and coal products, ceramics, stone and clay products, steel, non-ferrous metals, food, fabricated metals, industrial machinery, electrical machinery, transportation machinery and precision machinery for manufacturing industries and construction, real estate, wholesale, retail, transportation and information communication, and service for non-manufacturing industries.

${ }^{10}$ For the wholesale industry, medium-sized firms are defined as those with employees between 100 and 1,000, while small firms are defined as those with employees between 20 and 100. For retail, service, and lease industries, medium-sized firms are defined as those with employees between 50 and 1,000, while small firms are defined as those with employees between 20 and 50 .

${ }^{11}$ See Ogawa(2000) for detailed procedures for constructing market-valued land stock.

${ }^{12}$ For the judgment questions in the Tankan survey, the respondents are asked to answer on the lending attitude of financial institutions excluding seasonal factors. That is the reason why we do not seasonally adjust the proportion of firms perceiving the lending attitude to be severe.

${ }^{13}$ Constant terms including dummies for industry and firm size are suppressed in the table.

${ }^{14}$ Hibara (2001) takes a similar approach to test the prevalence of evergreening of loans. ${ }^{15}$ The correlation coefficient between the $\frac{\partial S_{t}}{\partial\left(\triangle F B A L A N C E_{t}\right)}$ estimates and the firms' borrowings-land ratio calculated by combining all the observations across firm size is 0.0735 and insignificant. 
${ }^{16}$ A statistically negative coefficient of the cross term is also obtained in petroleum and coal products, precision machinery, and service industries for medium-sized firms.

${ }^{17}$ The correlation coefficient between the $\frac{\partial S_{t}}{\partial\left(\triangle F B A L A N C E_{t}\right)}$ estimates and the firms' borrowings-land ratio, calculated by combining all the observations across firm size, is 0.0234 and insignificant.

${ }^{18}$ Nishimura et al. (2005) and Caballero et al. (2004) are interesting attempts along this line. 


\section{References}

[1] Berglöf E. and G. Roland(1995).”Bank Restructuring and Soft Budget Constraints in Financial Transition,” Journal of the Japanese and International Economies 9, pp.354-375.

[2] Berglöf E. and G. Roland(1997).” Soft Budget Constraints and Credit Crunches in Financial Transition,” European Economic Review 41, pp.807-817.

[3] Caballero, R.J., Hoshi,T. and A.K. Kashyap(2004).” Zombie Lending and Depressed Restructuring in Japan,” mimeographed.

[4] Dewatripont,M and E. Maskin(1995). “ Credit and Efficiency in Centralized and Decentralized Economies,” Review of Economic Studies 62, pp.541-555.

[5] Economic and Social Research Institute(1995). Keizai Hakusho (Economic White Paper), Printing Office, Ministry of Finance, (in Japanese).

[6] Fukao, M.(2000). Kin-yu Fukyo no Jissho Bunseki (Empirical Analyses of Financial Recession), Nihon Keizai Shinmbun-sha, (in Japanese).

[7] Fukuda, S., Kasuya, M. and J. Nakajima(2005).” Hijyojyo Kigyo ni “Oikashi” wa Sonzai Shitaka?” (Did Ever-greening of Loans Exist for Unlisted Firms?) The Bank of Japan Working Ppaer No.05-J-9.

[8] Hibara,N.(2002).” What Happens in Banking Crises? Moral Hazard vs. Credit Crunch,” mimeographed.

[9] Honda,Y. (2002).” The Effects of the Basle Accord on Bank Credit: The Case of Japan,” Applied Economics 34, pp.1233-1239. 
[10] Horie,Y.(2001). Ginko Kashidashi no Keizai Bunseki (Economic Analysis of Bank Lending), University of Tokyo Press (in Japanese).

[11] Hoshi,T.(2000).” Naze Nihon wa Ryudosei no Wana kara Nogarerarenainoka? (Why is the Japanese Economy Unable to Get Out of a Liquidity Trap?)” in Fukao,M. and H. Yoshikawa (eds.) Zero Kinri to Nihon Keizai (Zero Interest Rate and the Japanese Economy), Nihon Keizai Shimbunsha, pp.233-266,(in Japanese).

[12] Hosono,K.(2006).” The Transmission Mechanism of Monetary Policy in Japan: Evidence from Banks’ Balance Sheets,” Journal of the Japanese and International Economics 20, pp.380-405.

[13] Hosono,K. and M. Sakuragawa(2003).” Soft Budget Problems in the Japanese Credit Market,” mimeographed.

[14] Ito,T. and Y.N. Sasaki(2002).” Impacts of the Basle Capital Standard on Japanese Banks' Behavior," Journal of the Japanese and International Economics 16, pp.372-397.

[15] Kobayashi, K., Saita,Y. and T. Sekine(2002).” Forbearance Lending: A Case for Japanese Firms,” Research and Statistics Department Working Paper (Bank of Japan) Working Paper 02-2.

[16] Maeda,T.(1996).” Wagakuni Ginko-gyo niokeru Kashidasi Nobinayami nitsuite Kashishiburi Ron nikan-suru Kosatsu to Jissho Bunseki (Lending Problem of Japanese Banking Industry - An Empirical Study on Credit Crunch -)”, Financial Review (Policy Research Institute, Ministry of Finance), Vol. 39, pp.131-151,(in Japamese). 
[17] Miyagawa, T., Nosaka, H. and M. Hashimoto(1995).” Kin-yu Kankyo no Henka to Jittai Keizai (Change in Financial Environment and the Real Economy),” Chosa (Research) Vol.203, Development Bank of Japan (in Japanese).

[18] Nishimura,G.K., Nakajima,T. and K. Kiyota(2003).” Does the Natural Selection Mechanism Still Work in Severe Recessions? Examination of the Japanese Economy in the 1990s,” Journal of Economic Behavior \& Organization 58, pp.53-78.

[19] Ogawa,K.(2000).” Monetary Policy, Credit and Real Activity: Evidence from the Balance Sheet of Japanese Firms," Journal of the Japanese and International Economies 14, pp.385-407.

[20] Ogawa,K.(2003) Daifukyo no Keizai Bunseki (Economic Analysis of Depressions), Nihon Keizai Shimbunsha (in Japanese).

[21] Ogawa,K.(2004).” Debt, R\&D Investment and Technological Progress: A Panel Study of Japanese Manufacturing Firms in the 90s," Institute of Social and Economic Research (Osaka University) Discussion Paper No.607.

[22] Ohkusa,Y.(2002).” Kashishiburi to Shinsa Kino (Credit Crunch and Screening Function),” Mitani,N. and A.Wakisaka (eds.) Micro Business no Keizai Bunseki Cyusho Kigyo Keieisha no Jittai to Sono Koyo Sosyutsu (Economic Analysis of Micro Business - Realities of Entrepreneurs of Small Business and Job Creation - ), University of Tokyo Press, pp.145-160, (in Japanese).

[23] Peek J. and E. S. Rosengren(1997).” The International Transmission of Financial Shocks: The Case of Japan,” American Economic Review Vol.87, No.4, pp.495-505.

[24] Peek J. and E. S. Rosengren(2000).” Collateral Damage: Effects of the Japanese Bank Crisis on Real Activity in the United States,” American Economic Review 90, 
pp.30-45.

[25] Peek J. and E. S. Rosengren(2005).” Unnatural Selection: Perverse Incentives and the Misallocation of Credit in Japan,” American Economic Review 95, pp.1140-1166.

[26] Sakuragawa,M.(2002). Kin-yu Kiki no Keizai Bunseki (Economic Analysis of Financial Crisis), University of Tokyo Press (in Japanese).

[27] Sasaki,Y.(2000).” Jiko Shihon Hiritsu Kisei to Furyo Saiken no Ginko Kashidashi heno Eikyo (Effects of Regulation on Capital Adequacy Ratio and Non-Performing Loans on Bank Lending),” Uzawa,H. and M. Hanasaki (eds.) Kin-yu System no Keizaigaku (Economics of Financial System), University of Tokyo Press, pp.129-148, (in Japanese).

[28] Sugihara,S. and I.Fueta(2002).” Furyo Saiken to Oikashi (Non-Performing Loans and Ever-Greening), Nippon Keizai Kenkyu (JCER Economic Journal) No.44, pp.63-105, (in Japanese).

[29] Tsuru, K.(2001).” The Choice of Lending Patterns by Japanese Banks during the 1980s and 1990s: The Causes and Consequences of a Real Estate Boom,” IMES Discussion Paper No. 2001-E-8, Bank of Japan.

[30] Woo,D.(1998)." In Search of “Capital Crunch”: Supply Factors behind the Credit Slowdown in Japan,” IMF Working Paper WP/99/03.

[31] Yoshikawa,H., Eto, M. and T. Ike(1994).” Cyusho Kigyo nitaisuru Ginko niyoru Kashisiburi nitsuite (Credit Crunch by Banks to Small Firms),” Keizai Bunseki, Seisaku Kenkyu no Shiten Series (Economic Analysis, A Series of Policy Research) 1, (in Japanese). 
Figure 1

Density of $\theta_{i t}$

$f\left(\theta_{i t}\right)$

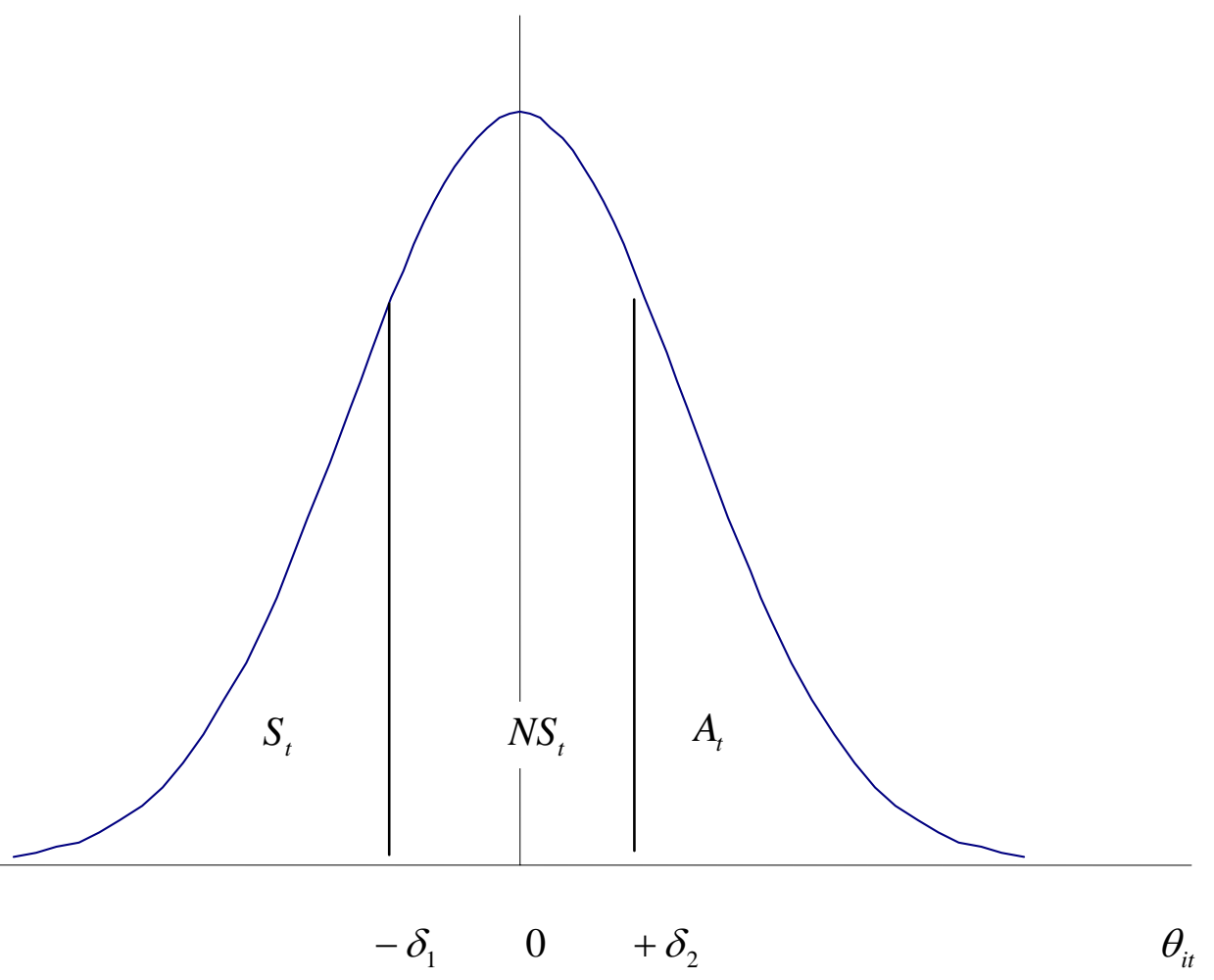


Figure 2

Shift of Density Function of $\theta_{i t}$

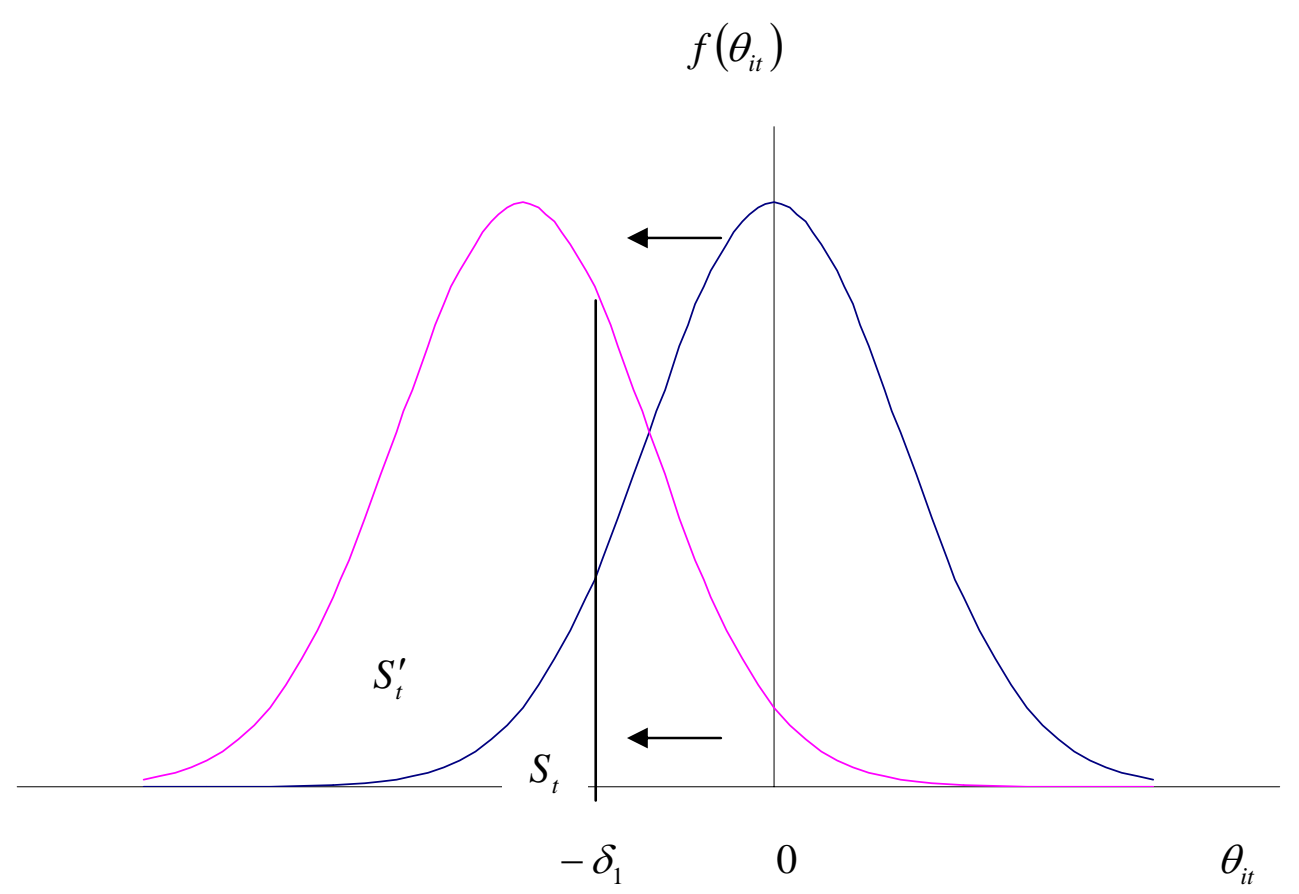


Table 1 Descriptive Statistics:

Ratio of Borrowing Outstandings to Market-Valued Land Stock

\begin{tabular}{|c|c|c|c|}
\hline & $\begin{array}{l}\text { Small } \\
\text { firms }\end{array}$ & $\begin{array}{l}\text { Medium-Sized } \\
\text { firms }\end{array}$ & $\begin{array}{l}\text { Large } \\
\text { firms }\end{array}$ \\
\hline \multicolumn{4}{|l|}{ Manufacturing industries } \\
\hline Food & 1.18 & 0.77 & 0.51 \\
\hline Textiles & 0.72 & 1.23 & 1.07 \\
\hline Lumber and wood products & 0.70 & 0.97 & 0.57 \\
\hline Paper and pulp & 0.82 & 0.91 & 1.39 \\
\hline Chemicals & 0.68 & 0.80 & 0.79 \\
\hline Petroleum and coal products & 0.68 & 2.28 & 1.29 \\
\hline Ceramics, stone and clay product & 0.99 & 0.91 & 0.83 \\
\hline Steel & 0.51 & 0.86 & 1.21 \\
\hline Non-ferrous metals & 0.94 & 1.71 & 1.71 \\
\hline Fabricated metals & 0.90 & 0.76 & 0.80 \\
\hline Industrial machinery & 1.11 & 1.13 & 0.66 \\
\hline Electrical machinery & 0.94 & 1.31 & 0.85 \\
\hline Transportation machinery & 0.70 & 0.81 & 0.32 \\
\hline Precision machinery & 0.92 & 0.72 & 0.80 \\
\hline Average & 0.84 & 1.08 & 0.91 \\
\hline \multirow{7}{*}{$\begin{array}{l}\text { Non-manufacturing industries } \\
\text { Construction } \\
\text { Wholesale } \\
\text { Retail } \\
\text { Real estate } \\
\text { Service } \\
\text { Transportation and information } \\
\text { commucication }\end{array}$} & & & \\
\hline & 0.98 & 1.33 & 1.60 \\
\hline & 0.96 & 1.31 & 2.67 \\
\hline & 0.95 & 0.95 & 0.50 \\
\hline & 1.00 & 1.15 & 1.11 \\
\hline & 0.72 & 1.59 & 3.15 \\
\hline & 1.00 & 0.84 & 1.09 \\
\hline Average & 0.93 & 1.19 & 1.69 \\
\hline
\end{tabular}

Data Source: The Financial Statements Statistics of Corporations by Industry 
Table 2 Descriptive Statistics:

Growth Rate of Real Sales

\begin{tabular}{|c|c|c|c|}
\hline & $\begin{array}{l}\text { Small } \\
\text { firms }\end{array}$ & $\begin{array}{l}\text { Medium-Sized } \\
\text { firms }\end{array}$ & $\begin{array}{l}\text { Large } \\
\text { firms }\end{array}$ \\
\hline \multicolumn{4}{|l|}{ Manufacturing industries } \\
\hline Food & -1.34 & -1.54 & -0.67 \\
\hline Textiles & -3.73 & 4.09 & -1.52 \\
\hline Lumber and wood products & -0.06 & 2.49 & -1.68 \\
\hline Paper and pulp & -0.94 & 0.64 & -0.09 \\
\hline Chemicals & 1.91 & 0.55 & 0.65 \\
\hline Petroleum and coal products & -0.82 & 6.30 & 2.11 \\
\hline Ceramics, stone and clay produc & -0.18 & 0.08 & -0.44 \\
\hline Steel & -1.06 & -0.36 & -0.53 \\
\hline Non-ferrous metals & -2.13 & 0.85 & -0.43 \\
\hline Fabricated metals & -2.24 & -1.54 & -1.19 \\
\hline Industrial machinery & 0.18 & 0.01 & -0.09 \\
\hline Electrical machinery & 2.88 & 5.65 & 3.28 \\
\hline Transportation machinery & 3.74 & 0.48 & 0.07 \\
\hline Precision machinery & 2.18 & -0.39 & 1.87 \\
\hline Average & -0.11 & 1.24 & 0.10 \\
\hline \multicolumn{4}{|l|}{ Non-manufacturing industries } \\
\hline Construction & -4.61 & -1.10 & -2.24 \\
\hline Wholesale & -2.36 & 0.28 & -3.93 \\
\hline Retail & -1.46 & -0.35 & -1.69 \\
\hline Real estate & 0.76 & -1.11 & 0.85 \\
\hline Service & -2.24 & -1.75 & 0.17 \\
\hline $\begin{array}{l}\text { Transportation and information } \\
\text { commucication }\end{array}$ & 0.15 & 1.37 & 4.33 \\
\hline Average & -1.63 & -0.44 & -0.42 \\
\hline
\end{tabular}

Data Source: The Financial Statements Statistics of Corporations by Industry 
Table 3

Estimation Results of Basic Lending Attitude Equation

\begin{tabular}{|c|c|c|}
\hline Variables & $\begin{array}{l}\text { Parameter } \\
\text { Estimates }\end{array}$ & t-value \\
\hline GROWTH & $1.045^{* * *}$ & 8.98 \\
\hline $\begin{array}{l}\text { Terms associated } \\
\text { with } \Delta \text { LIQ }\end{array}$ & & \\
\hline Constant & $1.0404^{* * *}$ & 4.04 \\
\hline DUMS & -0.3981 & -1.34 \\
\hline DUMM & -0.3171 & -1.01 \\
\hline \multicolumn{3}{|l|}{$\begin{array}{l}\text { Terms associated } \\
\text { with } \triangle \text { FBALANCE }\end{array}$} \\
\hline Constant & $-3.0099^{* * *}$ & -6.16 \\
\hline DUMS & $2.6054^{* * *}$ & 8.67 \\
\hline DUMM & $1.7731^{* * *}$ & 6.42 \\
\hline DUMIND1 & 0.5879 & 1.23 \\
\hline DUMIND2 & 0.0382 & 0.06 \\
\hline DUMIND3 & -0.5075 & -0.85 \\
\hline DUMIND4 & -0.9486 & -1.60 \\
\hline DUMIND5 & $1.2219^{* * *}$ & 2.56 \\
\hline DUMIND6 & -0.3953 & -0.61 \\
\hline DUMIND7 & -0.8897 & -1.31 \\
\hline DUMIND8 & 0.4731 & 0.91 \\
\hline DUMIND9 & $-1.9022^{* * *}$ & -2.73 \\
\hline DUMIND10 & -0.9097 & -1.56 \\
\hline DUMIND11 & -0.592 & -0.93 \\
\hline DUMIND12 & -0.9726 & -1.34 \\
\hline DUMIND13 & 0.0761 & 0.13 \\
\hline DUMIND14 & $-1.6957^{* *}$ & -2.35 \\
\hline DUMIND15 & -0.1805 & -0.33 \\
\hline DUMIND16 & -0.4261 & -0.66 \\
\hline DUMIND17 & $-2.6146^{* * *}$ & -3.12 \\
\hline DUMIND18 & $0.9063^{*}$ & 1.70 \\
\hline DUMIND19 & -0.9273 & -1.53 \\
\hline $\begin{array}{l}\text { Terms associated } \\
\text { with } \triangle \text { BBALANCE }\end{array}$ & & \\
\hline Constant & -12.8685 & -0.80 \\
\hline DUMS & 14.0278 & 1.60 \\
\hline DUMM & -6.7693 & -0.80 \\
\hline DUMIND1 & -24.4064 & -1.13 \\
\hline DUMIND2 & $40.1898^{*}$ & 1.93 \\
\hline DUMIND3 & -7.843 & -0.36 \\
\hline DUMIND4 & -6.4631 & -0.31 \\
\hline DUMIND5 & $-74.5895^{* * *}$ & -3.50 \\
\hline DUMIND6 & -11.0429 & -0.48 \\
\hline DUMIND7 & $-45.3541^{* *}$ & -2.04 \\
\hline DUMIND8 & -22.4138 & -0.98 \\
\hline DUMIND9 & 1.1467 & 0.05 \\
\hline DUMIND10 & -22.6438 & -1.00 \\
\hline DUMIND11 & -2.552 & -0.11 \\
\hline DUMIND12 & 3.5277 & 0.16 \\
\hline DUMIND13 & -5.5587 & -0.25 \\
\hline DUMIND14 & 8.5448 & 0.39 \\
\hline DUMIND15 & $-69.9243^{* * *}$ & -3.59 \\
\hline DUMIND16 & -6.1016 & -0.27 \\
\hline DUMIND17 & -11.4517 & -0.51 \\
\hline DUMIND18 & -19.1004 & -0.86 \\
\hline DUMIND19 & -31.7175 & -1.39 \\
\hline
\end{tabular}


Table 3 (Continued)

Estimation Results of Basic Lending Attitude Equation

\begin{tabular}{|c|cc|}
\hline Variables & $\begin{array}{l}\text { Parameter } \\
\text { Estimates }\end{array}$ & t-value \\
\hline Terms associated & & \\
with FBALANCE & & \\
BBBLANCE & & -1.15 \\
Constant & -356.8178 & 2.45 \\
DUMS & $498.0376^{* *}$ & 3.33 \\
DUMM & $578.465^{* * *}$ & -0.94 \\
DUMIND1 & $-292.8372^{* *}$ & -3.22 \\
DUMIND2 & $-988.9275^{* * *}$ & -0.76 \\
DUMIND3 & -323.6759 & 0.50 \\
DUMIND4 & 194.5783 & 0.29 \\
DUMIND5 & 86.4861 & 0.59 \\
DUMIND6 & 251.1433 & -1.47 \\
DUMIND7 & -573.8991 & -0.63 \\
DUMIND8 & -215.7686 & -0.39 \\
DUMIND9 & -178.7633 & 2.06 \\
DUMIND10 & $892.1184^{* *}$ & -0.98 \\
DUMIND11 & -406.2842 & -0.47 \\
DUMIND12 & -263.3822 & -2.86 \\
DUMIND13 & $-1092.19644^{* * *}$ & 0.18 \\
DUMIND14 & 85.4867 & -1.62 \\
DUMIND15 & -567.9458 & 0.63 \\
DUMIND16 & -205.6978 & 0.74 \\
DUMIND17 & 328.4504 & \\
DUMIND18 & 65.6554 & \\
DUMIND19 & 398.8008 & \\
\hline
\end{tabular}

Notes: DUMIND1 to DUMIND19 corresponds to the following industries: textiles, lumber and wood products, paper and pulp, chemicals, petroleum and coal products, ceramics, stone and clay products, steel, non-ferrous metals, fabricated metals, industrial machinery, electrical machiney, transportation machinery, precision machinery, construction, real estate, wholesale, retail, service and transportation and information communication.

$* * *, * *, * \quad$ significant at $1 \%, 5 \%$, and $10 \%$ level, respectively 
Table 4 Coefficient Estimates of the Cross Term

of Balance Sheet Variables of Firms and Banks

\begin{tabular}{|c|c|c|c|c|c|c|c|c|c|}
\hline & \multicolumn{3}{|c|}{ Small firms firms } & \multicolumn{3}{|c|}{ Medium-Sized firms } & \multicolumn{3}{|c|}{ Large firms } \\
\hline & Coefficient & & t-value & Coefficient & & t-value & Coefficient & & t-value \\
\hline Manufacturing industries & & & & & & & & & \\
\hline Food & 141.2198 & & 0.51 & 221.6472 & & 0.76 & -356.8178 & & -1.15 \\
\hline Textiles & -151.6175 & & -0.75 & -71.1900 & & -0.56 & -649.6551 & $* * *$ & -3.17 \\
\hline Lumber and wood products & -847.7078 & $* * *$ & -4.35 & -767.2803 & $* * *$ & -7.07 & -1345.7454 & $* * *$ & -7.05 \\
\hline Paper and pulp & -182.4562 & & -0.54 & -102.0287 & & -0.30 & -680.4938 & $*$ & -1.94 \\
\hline Chemicals & 335.7981 & & 1.13 & 416.2256 & & 1.39 & -162.2395 & & -0.49 \\
\hline Petroleum and coal products & 227.7059 & & 1.28 & 308.1333 & $* * *$ & 5.15 & -270.3317 & & -1.48 \\
\hline Ceramics, stone and clay product & 392.3630 & & 1.18 & 472.7905 & & 1.37 & -105.6745 & & -0.29 \\
\hline Steel & -432.6793 & & -1.42 & -352.2518 & & -1.28 & -930.7169 & $* * *$ & -2.97 \\
\hline Non-ferrous metals & -74.5489 & & -0.30 & 5.8786 & & 0.03 & -572.5865 & $* *$ & -2.32 \\
\hline Fabricated metals & -37.5435 & & -0.10 & 42.8839 & & 0.11 & -535.5811 & & -1.32 \\
\hline Industrial machinery & 1033.3382 & $* * *$ & 3.01 & 1113.7656 & & 3.10 & 535.3006 & & 1.40 \\
\hline Electrical machinery & -265.0644 & & -0.84 & -184.6369 & & -0.55 & -763.1020 & $* *$ & -2.15 \\
\hline Transportation machinery & -122.1624 & & -0.25 & -41.7349 & & -0.09 & -620.2000 & & -1.22 \\
\hline Precision machinery & -950.9767 & $* * *$ & -3.36 & -870.5492 & $* * *$ & -2.91 & -1449.0142 & $* * *$ & -4.91 \\
\hline \multicolumn{10}{|l|}{$\underline{\text { Non-manufacturing industries }}$} \\
\hline Construction & 226.7064 & & 0.54 & 307.1339 & & 0.75 & -271.3312 & & -0.68 \\
\hline Wholesale & -64.4780 & & -0.21 & 15.9494 & & 0.06 & -562.5156 & $*$ & -1.91 \\
\hline Retail & 469.6701 & & 0.98 & 550.0976 & & 1.12 & -28.3674 & & -0.06 \\
\hline Real estate & -426.7261 & $*$ & -1.73 & -346.2986 & & -1.49 & -924.7636 & $* * *$ & -3.44 \\
\hline Service & 206.8751 & & 0.76 & 287.3026 & & 1.11 & -291.1624 & & -1.13 \\
\hline $\begin{array}{l}\text { Transportation and information } \\
\text { commucication }\end{array}$ & 540.0206 & & 1.14 & 620.4481 & & 1.32 & 41.9830 & & 0.09 \\
\hline
\end{tabular}

$* * *, * *, * \quad$ significant at $1 \%, 5 \%$, and $10 \%$ level, respectively 
Table 5 Estimates of the Effects of Change in

Firms' Balance Sheet Conditions on Lending Attitude

\begin{tabular}{|c|c|c|c|c|c|c|c|c|c|}
\hline & \multicolumn{3}{|c|}{$\begin{array}{l}\text { Small } \\
\text { firms }\end{array}$} & \multicolumn{3}{|c|}{$\begin{array}{l}\text { Medium-Sized } \\
\text { firms }\end{array}$} & \multicolumn{3}{|c|}{$\begin{array}{l}\text { Large } \\
\text { firms }\end{array}$} \\
\hline & Estimate & & t-value & Estimate & & t-value & Estimate & & t-value \\
\hline Manufacturing industries & & & & & & & & & 6.22 \\
\hline Food & 0.0575 & & 0.87 & 0.1268 & $* * *$ & 2.67 & 0.2596 & $* * *$ & 7.70 \\
\hline Textiles & -0.0352 & & -0.53 & 0.1182 & $* *$ & 3.30 & 0.4734 & $* * *$ & 6.69 \\
\hline Lumber and wood products & 0.0911 & & 1.11 & 0.2832 & $* * *$ & 3.12 & 0.3398 & $* * *$ & 7.62 \\
\hline Paper and pulp & 0.1237 & $* *$ & 2.17 & 0.2353 & $* * *$ & 4.04 & 0.2205 & $* * *$ & 8.34 \\
\hline Chemicals & 0.1254 & $* * *$ & 2.97 & 0.1449 & $* * *$ & 5.08 & 0.3209 & $* * *$ & 5.75 \\
\hline Petroleum and coal products & -0.0637 & $* * *$ & -3.06 & -0.0069 & & -0.20 & 0.1966 & $* * *$ & 6.35 \\
\hline Ceramics, stone and clay product & 0.1265 & & 1.51 & 0.2344 & $* * *$ & 3.11 & 0.3772 & $* * *$ & 7.03 \\
\hline Steel & 0.2586 & $* *$ & 2.43 & 0.4294 & $* * *$ & 3.97 & 0.7709 & $* * *$ & 7.80 \\
\hline Non-ferrous metals & -0.0104 & & -0.16 & 0.0875 & $* *$ & 2.45 & 0.4398 & $* * *$ & 8.17 \\
\hline Fabricated metals & 0.3527 & $* * *$ & 4.06 & 0.3870 & $* * *$ & 5.31 & 0.9402 & $* * *$ & 8.07 \\
\hline Industrial machinery & 0.2072 & $* * *$ & 2.94 & 0.3296 & $* * *$ & 4.58 & 0.4990 & $* * *$ & 6.86 \\
\hline Electrical machinery & 0.1771 & $* *$ & 2.08 & 0.1820 & $* * *$ & 3.73 & 0.3904 & $* * *$ & 6.33 \\
\hline Transportation machinery & 0.2436 & $* *$ & 2.35 & 0.3224 & $* * *$ & 3.64 & 0.5143 & $* * *$ & 7.36 \\
\hline Precision machinery & 0.0914 & & 1.18 & 0.1490 & $* * *$ & 3.13 & 0.4068 & $* * *$ & \\
\hline$\underline{\text { Non-manufacturing industries }}$ & & & & & & & & & \\
\hline Construction & 0.3161 & $* * *$ & 3.46 & 0.3874 & $* * *$ & 4.92 & 0.7987 & $* * *$ & 7.84 \\
\hline Wholesale & 0.1433 & & 1.62 & 0.2474 & $* * *$ & 3.27 & 0.5233 & $* * *$ & 7.33 \\
\hline Retail & 0.6256 & $* * *$ & 4.09 & 0.7146 & $* * *$ & 5.11 & 0.8969 & $* * *$ & 7.40 \\
\hline Real estate & 0.1462 & $*$ & 1.92 & 0.3496 & $* * *$ & 3.82 & 0.7904 & $* * *$ & 7.63 \\
\hline Service & -0.1065 & & -1.48 & 0.0579 & & 0.86 & 0.3051 & $* * *$ & 6.06 \\
\hline $\begin{array}{l}\text { Transportation and information } \\
\text { commucication }\end{array}$ & 0.2110 & $* * *$ & 2.85 & 0.4247 & $* * *$ & 4.31 & 0.6008 & $* * *$ & 7.68 \\
\hline
\end{tabular}

$* * *, * *, * \quad$ significant at $1 \%, 5 \%$, and $10 \%$ level, respectively 
Table 6 Estimates of the Effects of Change in

Banks' Balance Sheet Conditions on Lending Attitude

\begin{tabular}{|c|c|c|c|c|c|c|c|c|c|}
\hline & \multirow{2}{*}{\multicolumn{3}{|c|}{$\begin{array}{l}\text { Small } \\
\text { firms }\end{array}$}} & \multicolumn{3}{|c|}{$\begin{array}{l}\text { Medium-Sized } \\
\text { firms }\end{array}$} & \multicolumn{3}{|c|}{$\begin{array}{l}\text { Large } \\
\text { firms }\end{array}$} \\
\hline & & & t-value & Estimate & & $\mathrm{t}$-value & Estimate & & t-value \\
\hline Manufacturing industries & & & & & & & & & \\
\hline Food & 0.3098 & & 0.11 & 2.0895 & & 1.21 & 1.3360 & & 0.99 \\
\hline Textiles & 5.0672 & & 1.42 & 7.5929 & $* *$ & 2.55 & 6.9521 & $* *$ & 2.33 \\
\hline Lumber and wood products & -7.3758 & $* * *$ & -2.72 & 5.1341 & $*$ & 1.68 & -1.4056 & & -0.92 \\
\hline Paper and pulp & 0.6296 & & 0.28 & 3.7898 & * & 1.74 & 1.8869 & * & 1.88 \\
\hline Chemicals & 0.0515 & & 0.03 & 0.9548 & & 0.81 & 1.6686 & & 1.38 \\
\hline Petroleum and coal products & 5.4113 & $* * *$ & 4.64 & 19.6540 & $* * *$ & 6.66 & 9.4143 & $* * *$ & 5.67 \\
\hline Ceramics, stone and clay produc & 2.6000 & & 0.79 & 4.9943 & $*$ & 1.81 & 2.8700 & & 1.44 \\
\hline Steel & 9.2257 & $* * *$ & 2.97 & 13.1728 & $* * *$ & 4.11 & 14.9811 & $* * *$ & 4.83 \\
\hline Non-ferrous metals & 4.1469 & & 1.31 & 4.8145 & $* *$ & 2.47 & 9.1931 & $* * *$ & 3.24 \\
\hline Fabricated metals & -0.2983 & & -0.11 & 2.2094 & & 1.03 & 2.3034 & & 0.70 \\
\hline Industrial machinery & -0.9233 & & -0.29 & 5.5964 & $* *$ & 1.97 & 3.8607 & * & 1.77 \\
\hline Electrical machinery & 1.0830 & & 0.36 & 2.4235 & & 1.41 & 3.1034 & * & 1.68 \\
\hline Transportation machinery & -0.7582 & & -0.25 & 2.3152 & & 0.88 & 1.6386 & & 0.77 \\
\hline Precision machinery & 2.4665 & & 0.83 & 2.5005 & & 1.33 & 7.8878 & $* * *$ & 3.64 \\
\hline$\underline{\text { Non-manufacturing industries }}$ & & & & & & & & & \\
\hline Construction & -1.9051 & & -0.73 & 1.4357 & & 0.65 & 1.8025 & & 0.60 \\
\hline Wholesale & 0.9141 & & 0.32 & 3.8230 & & 1.55 & 3.3738 & & 1.39 \\
\hline Retail & 1.6626 & & 0.45 & 5.2243 & & 1.58 & 3.9015 & & 1.41 \\
\hline Real estate & 15.1203 & $* * *$ & 5.20 & 20.3585 & $* * *$ & 6.32 & 19.9063 & $* * *$ & 6.61 \\
\hline Service & 3.4292 & & 1.03 & 8.9656 & $* * *$ & 2.59 & 3.4453 & & 1.43 \\
\hline $\begin{array}{l}\text { Transportation and information } \\
\text { commucication }\end{array}$ & 5.0051 & $*$ & 1.70 & 9.3501 & $* * *$ & 2.75 & 6.6592 & $* *$ & 2.48 \\
\hline
\end{tabular}

***,**,* significant at $1 \%, 5 \%$, and $10 \%$ level, respectively 
Table 7 Coefficient Estimates of the Cross Term

of Firms' Balance Sheet and the Rate of Change in Banks' Share Price

\begin{tabular}{|c|c|c|c|c|c|c|c|}
\hline & \multicolumn{2}{|c|}{ Small firms firms } & \multicolumn{3}{|c|}{ Medium-Sized firms } & \multicolumn{2}{|l|}{ Large firms } \\
\hline & Coefficient & t-value & Coefficient & & t-value & Coefficient & t-value \\
\hline Manufacturing industries & & & & & & & \\
\hline Food & 0.7295 & 0.22 & -3.1461 & & -0.91 & 0.0931 & 0.03 \\
\hline Textiles & 2.7348 & 1.40 & -1.1409 & & -0.83 & 2.0984 & 0.98 \\
\hline Lumber and wood products & 2.9718 & 0.77 & -0.9038 & & -0.24 & 2.3354 & 0.58 \\
\hline Paper and pulp & $3.9949 *$ & 1.79 & 0.1192 & & 0.05 & 3.3585 & 1.31 \\
\hline Chemicals & 1.1729 & 0.44 & -2.7027 & & -1.01 & 0.5365 & 0.18 \\
\hline Petroleum and coal products & 0.8445 & 0.55 & -3.0312 & $* * *$ & -3.74 & 0.2081 & 0.11 \\
\hline Ceramics, stone and clay product & -2.4232 & -0.52 & -6.2989 & & -1.36 & -3.0596 & -0.65 \\
\hline Steel & -3.0210 & -0.69 & -6.8967 & & -1.62 & -3.6574 & -0.83 \\
\hline Non-ferrous metals & $5.0576 * *$ & 2.20 & 1.1819 & & 0.52 & $4.4212 *$ & 1.87 \\
\hline Fabricated metals & 1.2102 & 0.40 & -2.6655 & & -0.83 & 0.5738 & 0.17 \\
\hline Industrial machinery & 4.0057 & 1.52 & 0.1300 & & 0.04 & 3.3693 & 1.07 \\
\hline Electrical machinery & 1.5704 & 0.46 & -2.3052 & & -0.70 & 0.9340 & 0.26 \\
\hline Transportation machinery & -1.4156 & -0.30 & -5.2912 & & -1.11 & -2.0520 & -0.42 \\
\hline Precision machinery & -2.5848 & -0.83 & -6.4605 & $* *$ & -2.06 & -3.2212 & -0.98 \\
\hline \multicolumn{8}{|l|}{ Non-manufacturing industries } \\
\hline Construction & -1.9316 & -0.46 & -5.8073 & & -1.40 & -2.5680 & -0.62 \\
\hline Wholesale & 4.2360 & 1.54 & 0.3603 & & 0.14 & 3.5996 & 1.44 \\
\hline Retail & 2.2487 & 0.42 & -1.6269 & & -0.30 & 1.6123 & 0.29 \\
\hline Real estate & $-4.6148 *$ & -1.88 & -8.4905 & $* * *$ & -3.31 & $-5.2512 *$ & -1.82 \\
\hline Service & 0.4582 & 0.23 & -3.4175 & $* *$ & -2.07 & -0.1782 & -0.09 \\
\hline $\begin{array}{l}\text { Transportation and information } \\
\text { commucication }\end{array}$ & 2.9457 & 0.64 & -0.9300 & & -0.20 & 2.3092 & 0.49 \\
\hline
\end{tabular}

*** ,**,* significant at 1\%, 5\%, and 10\% level, respectively 
Table 8 Estimates of the Effects of Firms' Balance Sheet Conditions

on Lending Attitude: Use of Banks' Share Price as Banks' Balance Sheet Conditions

\begin{tabular}{|c|c|c|c|c|c|c|c|c|c|}
\hline & \multicolumn{3}{|c|}{$\begin{array}{l}\text { Small } \\
\text { firms }\end{array}$} & \multicolumn{3}{|c|}{$\begin{array}{l}\text { Medium-Sized } \\
\text { firms }\end{array}$} & \multicolumn{3}{|c|}{$\begin{array}{l}\text { Large } \\
\text { firms }\end{array}$} \\
\hline & Estimate & & t-value & Estimate & & t-value & Estimate & & t-value \\
\hline Manufacturing industries & & & & & & & & & \\
\hline Food & 0.1114 & & 1.53 & 0.1067 & $* *$ & 2.04 & 0.2253 & $* * *$ & 4.85 \\
\hline Textiles & 0.0484 & & 0.74 & 0.0877 & $* * *$ & 3.63 & 0.4010 & $* * *$ & 6.12 \\
\hline Lumber and wood products & 0.1938 & $* *$ & 2.33 & 0.2881 & $* * *$ & 3.23 & 0.3192 & $* * *$ & 5.95 \\
\hline Paper and pulp & 0.1784 & $* * *$ & 2.80 & 0.2179 & $* * *$ & 3.27 & 0.1995 & $* * *$ & 6.05 \\
\hline Chemicals & 0.1226 & $* * *$ & 2.58 & 0.1055 & $* * *$ & 3.38 & 0.2571 & $* * *$ & 5.93 \\
\hline Petroleum and coal products & -0.0750 & $* * *$ & -3.24 & -0.1432 & $* * *$ & -4.26 & 0.0984 & $* *$ & 2.53 \\
\hline Ceramics, stone and clay product & 0.0935 & & 0.97 & 0.1230 & & 1.42 & 0.2719 & $* * *$ & 4.02 \\
\hline Steel & 0.1938 & & 1.58 & 0.2547 & $* *$ & 2.04 & 0.5607 & $* * *$ & 4.43 \\
\hline Non-ferrous metals & 0.0974 & & 1.32 & 0.0919 & $* *$ & 2.21 & 0.4101 & $* * *$ & 6.31 \\
\hline Fabricated metals & 0.3377 & $* * *$ & 3.16 & 0.3072 & $* * *$ & 3.46 & 0.7782 & $* * *$ & 5.57 \\
\hline Industrial machinery & 0.2827 & $* * *$ & 3.08 & 0.3079 & $* * *$ & 3.40 & 0.4539 & $* * *$ & 5.90 \\
\hline Electrical machinery & 0.1843 & $*$ & 1.94 & 0.1326 & $* *$ & 2.45 & 0.3149 & $* * *$ & 4.93 \\
\hline Transportation machinery & 0.1960 & & 1.63 & 0.2031 & $* *$ & 1.96 & 0.3839 & $* * *$ & 4.05 \\
\hline Precision machinery & -0.1026 & & -1.04 & -0.0310 & & -0.53 & 0.1771 & $* * *$ & 2.63 \\
\hline Non-manufacturing industries & & & & & & & & & \\
\hline Construction & 0.3142 & $* * *$ & 3.02 & 0.3122 & $* * *$ & 3.48 & 0.6683 & $* * *$ & 5.82 \\
\hline Wholesale & 0.2336 & $* *$ & 2.09 & 0.2449 & $* *$ & 2.53 & 0.4887 & $* * *$ & 5.24 \\
\hline Retail & 0.5690 & $* * *$ & 3.16 & 0.5601 & $* * *$ & 3.42 & 0.7330 & $* * *$ & 5.16 \\
\hline Real estate & 0.0988 & & 1.23 & 0.1695 & $*$ & 1.70 & 0.5597 & $* * *$ & 4.89 \\
\hline Service & -0.1315 & & -1.36 & -0.0795 & & -0.82 & 0.1791 & $* * *$ & 2.62 \\
\hline $\begin{array}{l}\text { Transportation and information } \\
\text { commucication }\end{array}$ & 0.2647 & $* * *$ & 2.67 & 0.3772 & $* * *$ & 2.94 & 0.5325 & $* * *$ & 5.32 \\
\hline
\end{tabular}

$* * *, * *, * \quad$ significant at $1 \%, 5 \%$, and $10 \%$ level, respectively 
Table 9 Estimates of the Effects of the Rate of Change in Banks' Share Price

on Lending Attitude: Use of Banks' Share Price as Banks' Balance Sheet Conditions

\begin{tabular}{|c|c|c|c|c|c|c|c|c|c|}
\hline & \multicolumn{3}{|c|}{$\begin{array}{l}\text { Small } \\
\text { firms }\end{array}$} & \multicolumn{3}{|c|}{$\begin{array}{l}\text { Medium-Sized } \\
\text { firms }\end{array}$} & \multicolumn{3}{|c|}{$\begin{array}{l}\text { Large } \\
\text { firms }\end{array}$} \\
\hline & Estimate & & t-value & Estimate & & t-value & Estimate & & t-value \\
\hline Manufacturing industries & & & & & & & & & \\
\hline Food & -0.1346 & $* * *$ & -3.62 & -0.1203 & $* * *$ & -4.59 & -0.0951 & *** & -4.37 \\
\hline Textiles & -0.2145 & $* * *$ & -3.54 & -0.2196 & $* * *$ & -4.64 & -0.2222 & $* * *$ & -4.32 \\
\hline Lumber and wood products & 0.0556 & & 1.02 & 0.0286 & & 0.35 & 0.0076 & & 0.23 \\
\hline Paper and pulp & -0.0942 & $* * *$ & -2.84 & -0.1320 & $* * *$ & -3.88 & -0.0622 & $* * *$ & -3.79 \\
\hline Chemicals & -0.0721 & $* * *$ & -2.99 & -0.0602 & $* * *$ & -3.31 & -0.0763 & $* * *$ & -3.78 \\
\hline Petroleum and coal products & -0.0911 & $* * *$ & -4.39 & -0.2948 & $* * *$ & -5.47 & -0.1537 & $* * *$ & -5.09 \\
\hline Ceramics, stone and clay produc & -0.0787 & & -1.64 & -0.1035 & $* *$ & -2.42 & -0.0636 & $*$ & -1.65 \\
\hline Steel & -0.0923 & & -1.42 & -0.1391 & $* *$ & -2.13 & -0.1240 & * & -1.73 \\
\hline Non-ferrous metals & -0.1530 & $* * *$ & -3.15 & -0.1138 & $* * *$ & -3.74 & -0.1857 & $* * *$ & -3.74 \\
\hline Fabricated metals & -0.0926 & $* *$ & -2.09 & -0.0972 & $* * *$ & -2.65 & -0.1524 & $* * *$ & -2.88 \\
\hline Industrial machinery & -0.1680 & $* * *$ & -2.95 & -0.1771 & $* * *$ & -3.66 & -0.1401 & $* * *$ & -3.63 \\
\hline Electrical machinery & -0.1491 & $* * *$ & -2.90 & -0.1020 & $* * *$ & -3.55 & -0.1128 & $* * *$ & -3.53 \\
\hline Transportation machinery & -0.1089 & $* *$ & -2.22 & -0.1282 & $* * *$ & -3.28 & -0.1045 & $* * *$ & -2.91 \\
\hline Precision machinery & -0.0987 & $*$ & -1.91 & -0.0914 & $* * *$ & -3.07 & -0.0852 & $* *$ & -2.17 \\
\hline Non-manufacturing industries & & & & & & & & & \\
\hline Construction & -0.1045 & ** & -2.22 & -0.1245 & & 0.65 & -0.1443 & ** & -2.53 \\
\hline Wholesale & -0.1554 & $* * *$ & -3.25 & -0.1662 & & 1.55 & -0.1665 & $* * *$ & -4.02 \\
\hline Retail & -0.1741 & $* *$ & -2.34 & -0.1946 & & 1.58 & -0.1641 & $* * *$ & -2.93 \\
\hline Real estate & -0.2381 & $* * *$ & -4.10 & -0.3259 & $* * *$ & 6.32 & -0.2981 & $* * *$ & -4.77 \\
\hline Service & -0.1658 & $* * *$ & -3.14 & -0.2292 & $* * *$ & 2.59 & -0.1490 & $* * *$ & -4.05 \\
\hline $\begin{array}{l}\text { Transportation and information } \\
\text { commucication }\end{array}$ & -0.1471 & $* * *$ & -2.73 & -0.2224 & $* * *$ & 2.75 & -0.1728 & $* * *$ & -2.93 \\
\hline
\end{tabular}

***,**,* significant at $1 \%, 5 \%$, and $10 \%$ level, respectively 